\title{
Festival umení Konfrontácie 2021
}

\section{Zuzana Hubinská, Ivana Lacková, Dominika Sondorová}

V dňoch 22. až 26. novembra 2021 sa uskutočnil už 18. ročník festivalu umení s medzinárodnou účastou - Konfrontácie 2021. Aj napriek nepriaznivej epidemickej situácii ožili priestory nitrianskej Synagógy a Pavilónu hudby v Nitre umením renomovaných slovenských i zahraničných interpretov. S festivalom je už tradične spätá výstava súčasného slovenského výtvarného umenia. Pod názvom Hladiny/Levels v tomto roku na nej svoje diela predstavil Marko Vrzgula, ktorého pôvodne kresliarske skice sa dostávajú na povrch vel'kých plátien. Vernisáž výstavy sa pod kuratelou doc. PhDr. Adriany Réckej, PhD. uskutočnila $v$ deň otvorenia festivalu - v pondelok 22. novembra o 18.00 hod. Cyklus obrazov Hladiny, ktorý gestami i farebnostou konvenoval s bohatou a zvukovo farebnou hudobnou dramaturgiou 18. ročníka festivalu, mal byt’ záujemcom o výtvarné umenie pôvodne dostupný až do 17. decembra 2021, avšak v dôsledku opatrení v súvislosti s vývojom epidemickej situácie na Slovensku sa brány nitrianskej Synagógy zavreli už vo štvrtok 25. novembra 2021, a tak obrazy osireli. Zostáva len dúfat', že s touto tvorbou Marka Vrzgulu sme sa nestretli posledný raz a že priaznivci jeho maliarskeho umenia sa ňou budú môct' kochat' v inom prostredí a v inom čase...

Počas festivalu odznelo pät' večerných koncertov, ktoré boli súčasne online streamované a odvysielané v programe Západoslovenskej televízie.

\section{Pondelok 22. november / $18.00 \mathrm{~h}$}

Osemnásty ročník festivalu umení Konfrontácie otvorilo unikátne hudobné zoskupenie Czech Slovak Cello Quartet, ktoré vzniklo v roku 2018 pri príležitosti 100. výročia založenia Československej republiky. Jeho členovia Jiří Hanousek (CZ), Aleš Kaspřík (CZ), Eugen Prochác (SK) a Ján Slávik (SK) sú významnými osobnostami violončelovej hry v oboch krajinách. Venujú sa nielen umeleckej a koncertnej činnosti, ale sú tiež zanietenými pedagógmi violončelovej hry. Jiří Hanousek je laureátom Pražskej jari, sólovým violončelistom Ostravskej filharmónie a pedagógom Ostravskej univerzity. Aleš Kaspř́í je dlhoročným a zakladajúcim členom Wihanovho kvarteta, vít’azom sútaží 


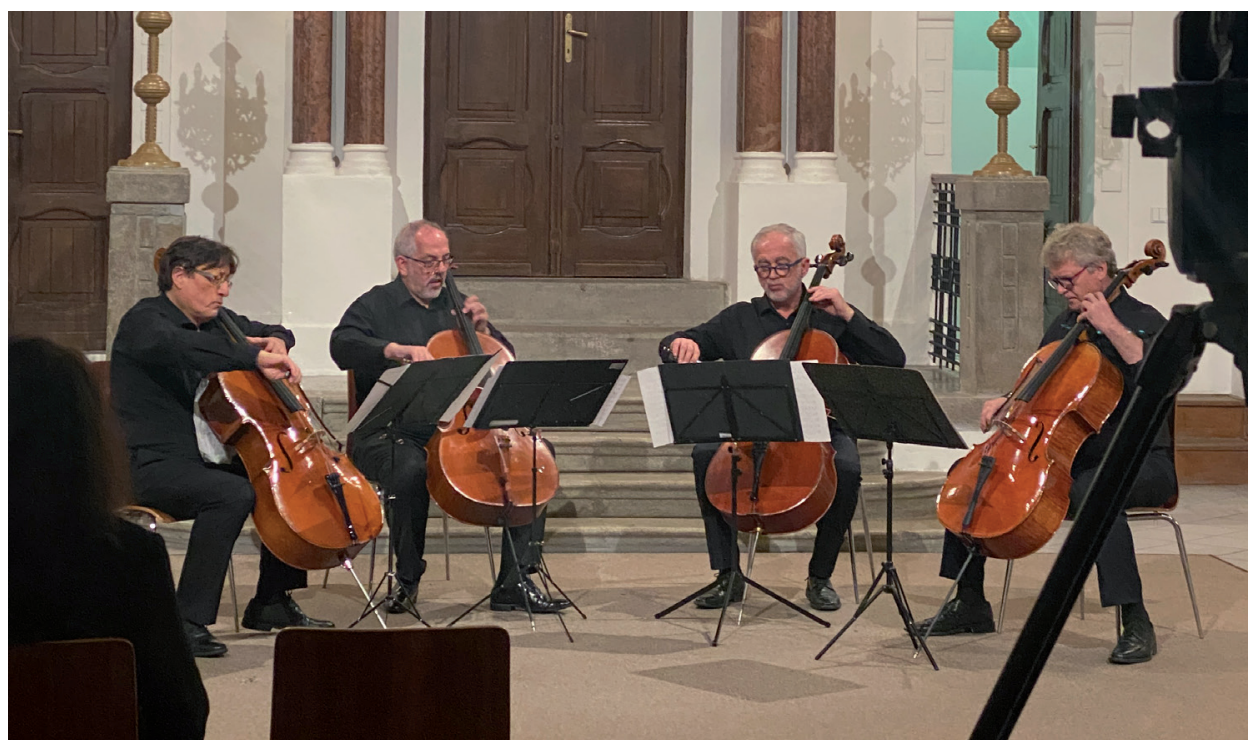

Obr. 1: Czech Slovak Cello Quartet, 22. 11. 2021

v Prahe, Londýne a v Trapani. Eugen Prochác sa stal absolútnym vít’azom Interpretačnej sútaže Slovenska a vítazom medzinárodnej sútaže Premio Valentino Bucchi v Ríme. Ján Slávik je sólovým violončelistom Slovenskej filharmónie, členom Moyzesovho kvarteta, laureátom sútaže v Eviane a pedagógom VŠMU. Všetci členovia kvarteta sú tiež známi z umeleckej spolupráce s elitnými orchestrami a v neposlednom rade sú vybavení dávkou talentu a umeleckých ambícií. Preto títo renomovaní sólisti s dlhoročnými skúsenost’ami spojili svoje sily a vytvorili originálny súbor štyroch violončiel s ambíciou dlhodobého pravidelného účinkovania.

Kvarteto má na svojom konte viaceré úspechy. V roku 2018 sa zúčastnilo slovenského festivalu Peknej hudby v Banskej Štiavnici a na slovenskom festivale umenia Hudba Trnave, kde zaznamenalo zaslúžený obdiv za svoje interpretačné umenie. V roku 2020 bolo Czech Slovak Cello Quartet nominované na Cenu „Jantar“ v oblasti vážnej hudby. V tom istom roku hudobníci nahrali a pokrstili svoj prvý hudobný album s názvom Music For Cello Quartet, na ktorom sa nachádzajú skladby pre violončelové kvarteto od P. Šimaia, I. Zeljenku, J. Kolkoviča, R. Haasa a M. Krajčiho. V roku 2020 bolo Czech Slovak Cello Quartet nominované na cenu Radio Head Awards za najlepšiu nahrávku klasickej hudby na Slovensku.

Na otváracom koncerte v podaní súboru Czech Slovak Cello Quartet zazneli nasledujúce skladby: Pavol Šimai (1930) Tack (Vd’aka), Georg Eduard Goltermann (1824 - 1898) Serenade, David Popper (1843 - 1913) Polonaise de Concert, Ilja Zeljenka (1932 - 2007) Musica Slovaca, Roman Haas (1980) Violončelové kvarteto č. 1 Vyšehradské.

Hudobnú čast’ festivalu otvorila prostá, krátka skladbička Pavla Šimaia Tack, ktorá vznikla z jednoduchého nápadu periodickej melódie nepárneho metra, ako svojho času poznamenal skladatel'. $\mathrm{K}$ tejto jednoduchej melódii skladatel' dokomponoval "cantus firmus" na spôsob barokových organových chorálových predohier, pričom kontrast oboch zložiek zdôraznil odlišnou artikuláciou violončelovej hry - pizzcato 
kontra kantiléna v hre so sláčikovými nástrojmi. Nasledujúca Serenáda Georga Eduarda Goltermanna, nemeckého romantického skladatel'a a vynikajúceho violončelistu, predstavuje typicky romantickú kompozíciu s nutnou dávkou sentimentu, no i s pozoruhodnou melodikou a prirodzenou violončelovou technikou, ktoré boli autorovi také blízke a ktoré violončelisti dodnes pozitívne oceňujú. Azda toto je ten dôvod, pre ktorý jeho diela pre violončelo (na rozdiel od inej tvorby) stále ožívajú na koncertných pódiách. Podobne ako k tvorbe G. E. Goltermanna sa kritika stavala aj k tvorbe jeho žiaka - Davida Poppera, ktorý bol verejnosti svojej doby známy najmä ako famózny violončelista s krásnym spevným tónom, technickou dokonalost’ou, a predovšetkým umením hry vysokých tónov. Skladby D. Poppera, ktoré venoval svojmu oblúbenému nástroju, sa vyznačujú neobyčajnou technickou náročnostou, ale i výrazovou a melodickou pôsobivostou. Takou nesporne je aj jeho Polonaise de Concert, ktorá zaznela v pôsobivej interpretácii súboru Czech Slovak Cello Quartet. Milovníkov hudby Ilju Zeljenku nepochybne potešilo jeho azda najznámejšie dielo Musica Slovaca, v ktorom sa snúbi hravost' rytmu s inšpiráciami slovenského folklóru. Invenčná a interpretačne vd’ačná skladba s typicky zeljenkovskou poetikou zaznieva z koncertných pódií vo viacerých autorských spracovaniach. Verzia pre violončelové kvarteto pochádza z roku 2003 a Czech Slovak Cello Quartet sa jej zhostil s interpretačným nadhladom a radostou, prýštiacou z porozumenia a vzájomného muzicírovania. Záverečné Vyšehradské kvarteto č. 1 českého súčasného skladatela Romana Haasa vzniklo pri príležitosti predsedníctva Slovenskej republiky v čele V4 počas rokov 2014 - 2015. Ide o svojrázny variačný cyklus zložený zo štyroch častí, v ktorých sa skladatel' nechal inšpirovat' tvorbou skladatel'ov, prináležiacich do V4 - F. Chopinom, B. Bartókom, A. Dvořákom a v prípade Slovenska melódiou slovenskej hymny Nad Tatrou sa blýska. Dokonalá súhra, zvuková farebnost’ a vyváženost’ nástrojov či spevná kantiléna umocnili zážitok z tejto hudobnej hádanky pre poslucháčov. Komorný súbor Czech Slovak Cello Quartet si svojím výkonom získal publikum, ktoré si vyžiadalo prídavok - Sarabandu zo Suity pre sólové violončelo od J. S. Bacha v úprave pre štyri violončelá. Československé hudobné teleso zložené zo štyroch violončiel nepochybne prinieslo do diania festivalu závan spontánneho a tvorivého muzikantstva. Zretel'ná artikulácia, „,'čitatel'né“ kontúry každého hráča, komplexný zvuk, citlivá vzájomná komunikácia, kultivovaný temperament, osobitá schopnost' presnej definície fráz - tak možno charakterizovat’ prvý festivalový koncert v podaní Czech Slovak Cello Quartet.

\section{Utorok 23. november / $18.00 \mathrm{~h}$}

Počas druhého koncertu sa predstavil Karol Kompas, ambiciózny slovenský gitarista a skladatel.' Gitare sa začal venovat’ už počas štúdia na Konzervatóriu v Žiline, pokračoval na VŠMU v Bratislave a doktorandské štúdium úspešne ukončil na Katedre hudby UKF v Nitre. V rokoch 2000 - 2001 absolvoval ročný študijný pobyt v Pol'sku na Hudobnej Akadémii v Katowiciach, kde študoval gitaru u Aliny Gruszky a Wandy Palacz. Vo svojej umeleckej kariére absolvoval množstvo majstrovských kurzov, zúčastnil sa na domácich a zahraničných sútažiach, vystupoval na rôznych festivaloch (Wetterfest vo Viedni, Samba Syndrom v Berlíne, Festival Muzyka i wino v Zielonej Góre v Pol'sku a d'.). Ako sólový i komorný hráč spolupracoval s viacerými slovenskými aj zahraničnými hudobnými zoskupeniami. Je zakladatelom súborov Mertz Guitar Duo (s Vladimírom Ondrejčákom, zal. 2009) a PiaTango Project (zal. 2017) - súboru 
zameraného na argentínske Tango Nuevo a na tvorbu Astora Piazzollu, s ktorým v roku 2019 absolvoval sériu koncertov s názvom Príbehy argentínskeho tanga. Popri klasickej hudbe, kde v slovenskej alebo svetovej premiére uviedol niekol'ko diel slovenských autorov (P. Krška, J. Iršai, A. Döme), sa aktívne prezentuje aj v oblasti pop-rocku, jazzu, improvizácie a komponovania.

$\checkmark$ rámci druhého koncertného dňa 18. ročníka festivalu umení Konfrontácie sa Karol Kompas predstavil s programom Pät'storočí gitary na Slovensku, ktorý obsahoval sólovú gitarovú a lutnovú hudbu z obdobia 16. až 21. storočia. V úvode koncertu Karol Kompas predstavil pôvodne lutnové skladby nemeckého renesančného skladatel'a Hansa Neusiedlera (1508 - 1563). Doménou H. Neusiedlera bola hra na lutne, ktorou sa preslávil až potom, čo sa usadil v nemeckom Norimbergu. V rokoch 1536 až 1549 vydal osem kníh lutnovej hudby, obsahujúcich upravené nemecké piesne, francúzske šansóny, talianske madrigaly, tanečné skladby a prelúdiá improvizačného charakteru. Výber z jeho tvorby v transkripcii pre gitaru - Preambel, Ein Guts Hofftantzlein Für Ein Schüler / Der Hupff Auff, Wascha Mesa / Der Hupff Auff, Entlaubt Ist Uns Der Walde, Ein Tuger Welscher Tanz / Der Hupff Auff a Gassenhawer - zaznel v presvedčivej interpretácii K. Kompasa. Aj nasledujúce skladby z obdobia hudobného baroka a klasicizmu na Slovensku patrili pôvodne lutne. Barok reprezentovali skladby z hudobnej zbierky Vietorisova tabulatúra (17. storočie) - Klobucký tanec/Proportio, Ach smutná, Ne takes my mluvel, Nerada robila som. Ide o významný hudobný prameň poukazujúci predovšetkým na rozšírenie nástrojovej hudby na území Slovenska v 17. storočí a zároveň dokumentujúci rôzne vrstvy dobovej hudobnej kultúry: šl'achtickú a mestskú umelú hudbu, ako aj l'udovú a cirkevnú hudbu. Sólový koncert pokračoval dvoma častami - Fantasie a Fuga zo Sonáty a mol od Paula Charlesa Duranta (1712 - 1769), ktorý patril k výrazným osobnostiam lutnovej hudby 18. storočia. Dielo európskeho lutnistu, ktorý bol od roku 1754 prvým dvorným lutnistom v Bayreuthe, obsahuje sólovú koncertnú, aj komornú lutnovú hudbu. Karol Kompas si zvolil dramaturgiu, ktorá na jednej strane rešpektovala dobové barokové a klasicistické interpretačné zvyklosti lutnovej hry, na druhej strane však vystihol mieru kontrastnosti uvádzaných drobných skladbičiek a udržal pozornost’ poslucháča stupňujúcou sa líniou interpretačnej náročnosti.

Rané romantické obdobie Kompas poslucháčom priblížil tvorbou rakúsko-uhorského gitaristu a skladatel’a Josepha Kaspara Mertza (1806 - 1856). Prostredníctvom vybraných skladieb - An Malvina, Sehnsucht a Scherzo - interpret predstavil rozsiahly cyklus 10 zväzkov skladieb s názvom Bardenklänge op. 13, ktorý sa považuje za autorov najvýznamnejší prínos do gitarového repertoáru. Krátke diela vychádzajú z tradície ducha charakterových skladbičiek F. M. Bartholdyho (Piesne bez slov), R. Schuberta (Moments musicaux) či klavírnych miniatúr R. Schumanna. Mertz v nich dokonale zachytáva poetiku týchto diel a dodáva im fantazijné či folklórne názvy, prípadne odkazuje na literatúru (nechal sa teiž inšpirovat' Ossianovými básňami, ktoré mali vo všeobecnosti vel'ký vplyv na vývoj romantizmu v umení). Karol Kompas vybraným dielam dodal potrebnú virtuozitu a zmysel pre štýl s dôrazom na čistotu a krásu zvuku.

Pomyselnú druhú polovicu koncertu Karol Kompas otvoril skladbami Pochod, Nokturno a Gajdoš od slovenského klaviristu a skladatela Dušana Martinčeka (1936 - 2006). Tvorba D. Martinčeka prešla viacerými fázami: zo začiatku sa koncentroval prevažne na klavírne opusy, v d’alšom období smeroval k väčšej tvarovej 
i farebno-zvukovej vynaliezavosti a k syntéze kontrastných prvkov. Charakteristickou pre jeho tvorbu je oscilácia medzi jemnou lyrikou a živelným prejavom, úcta k tradícii nástrojovej štylizácie, v neskoršej tvorbe uvolnenej smerom $k$ expresívnejšiemu prejavu, ako aj príležitostnými výrazovými prvkami folklórnych inšpirácií. Koncert pokračoval dielom Miniatúry pre gitaru z roku 1994/1995 od slovenského hudobného skladatela Pavla Kršku (1949), ktorého hudobná poetika je ovplyvnená väzbami na slovenský folklór a súčasne vyniká kompozičnou originalitou a využitím zvukových možností rôznych nástrojov. Pätčastové dielo Miniatúry pre gitaru vzniklo na objednávku gitaristu Jána Labanta. Kompas divákom predviedol všetkých pät' častí - Modlitba všedného dňa (Presto), Modlitba prosebná (Allegretto),

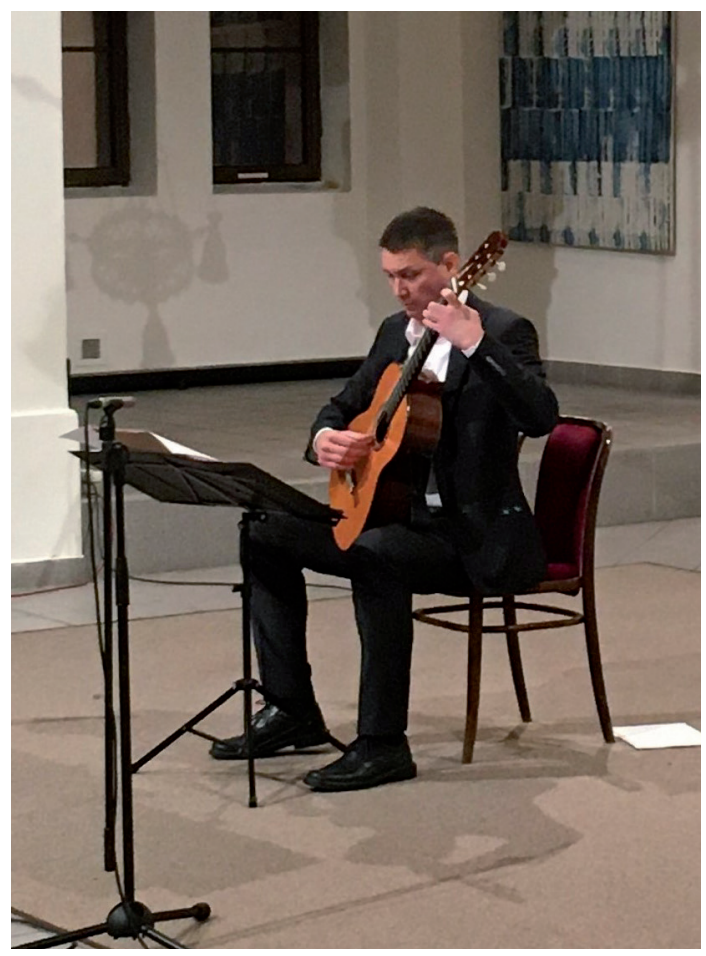

Obr. 2: Karol Kompas, 23. 11. 2021 Modlitba d'akovná (Presto), Modlitba v smútku (Allegretto), Modlitba v radosti (Prestissimo). Diel oboch slovenských skladatelov sa K. Kompas zhostil s potrebnou dávkou nadhladu a so zmyslom pre čistotu intonácie a rytmickú precíznost'.

V dramaturgickej výstavbe koncertu v rámci 18. ročníka festivalu Konfrontácie sa gitarista Karol Kompas (1975) predstavil aj ako skladatel', a to dielom Tango motorico. Vystupovanie Kompasa pôsobilo uvol'nene, v niektorých momentoch citlivo osobne, obohatené o presvedčivý hudobný výraz a virtuozitu. Predposledný bod programu venoval tvorbe významného predstavitela slovenskej experimentálnej a alternatívnej hudby 80. a 90. rokov 20. storočia Petra Machajdíka (1961), ktorý si vo svojej tvorbe často kladie otázky o súčasnej dobe a spoločnosti, nabádajúc k humánnosti a zodpovednosti voči svetu i sebe navzájom. Hoci sa pôsobenie P. Machajdíka od roku 1992 presunulo do Nemecka, nespretŕhal kontakty so Slovenskom a nad’alej komponuje diela aj pre slovenských interpretov. HÍbavá gitarová skladba Silent Wanderings (Tiché putovania), ktorú Kompas s úprimným zaujatím pre filozofické posolstvo poslucháčom predstavil, je súčastou albumu The Immanent Velvet (Imanentný zamat, 2012), kde sa nachádza desat’ kompozícií pre rôzne nástrojové obsadenie. Pestrý program hudobnej tvorby pre gitaru slovenských autorov naprieč 20. a 21. storočím uzavrela premiéra Etudy č. 1 pre gitaru od skladatel'a ruského pôvodu Jevgenija Iršaia (1951). Diela J. Iršaia zosobňujú jeho vnútorný svet, súzvuk alebo rozpor jeho bytia s obklopujúcim ho svetom, či jeho energiu a potenciál. Skladatel' víta výzvy od interpretov, a tak jeho tvorbu obohatili aj skladby venované gitare. Karol Kompas počas celého 
koncertu disponoval zanietením, profesionálnym prístupom a citel'nou zručnostiou v štýlovej čistote v kontexte historických relácií. Prít’ǎlivý program koncertu, ktorý sa niesol v komornej atmosfére, poslucháčov zaujal nielen vd’aka skladbám slovenských autorov prepájajúcim históriu a súčasnost', ale aj vd’aka profesionálnej ukážke rôznych techník hry na gitare.

\section{Streda 24. november / $18.00 \mathrm{~h}$}

V stredu večer do priestorov nitrianskej Synagógy zavítal slovenský komorný súbor Trio Elfair, zložený z významných slovenských interpretov - Jevgenija Iršaia (klavír), Ladislava Fanzowitza (klavír, barytónový saxofón) a Jozefa Eliáša (klarinet). Klavirista, skladatel' a pedagóg Jevgenij Iršai, pôvodom z Ruska, v tomto roku oslávil významné životné jubileum, a tak dramaturgia festivalového večera priniesla výlučne pohlad na minulú i novú autorskú tvorbu skladatela, ktorého diela pravidelne zaznievajú na slovenských i svetových koncertných pódiách.

Slovenský klavirista a všestranný muzikant Ladislav Fanzowitz absolvoval štúdium na Konzervatóriu v Bratislave, Akadémii múzických umení v Prahe, Universität für Musik und darstellende Kunst vo Viedni a na VŠMU v Bratislave. Pravidelne vystupuje s mnohými významnými slovenskými a českými orchestrami, ako napríklad so Slovenskou filharmóniou, Symfonickým orchestrom Slovenského rozhlasu, Symfonickým orchestrom Českého rozhlasu, Pražskou komornou filharmóniou a i. Epiteton všestranný umelec pri mene Ladislava Fanzowitza potvrdzuje aj dlhodobý záujem o džezovú hudbu, založenie swingového orchestra Fats Jazz Band či saxofónového kvarteta Saxophone Syncopators.

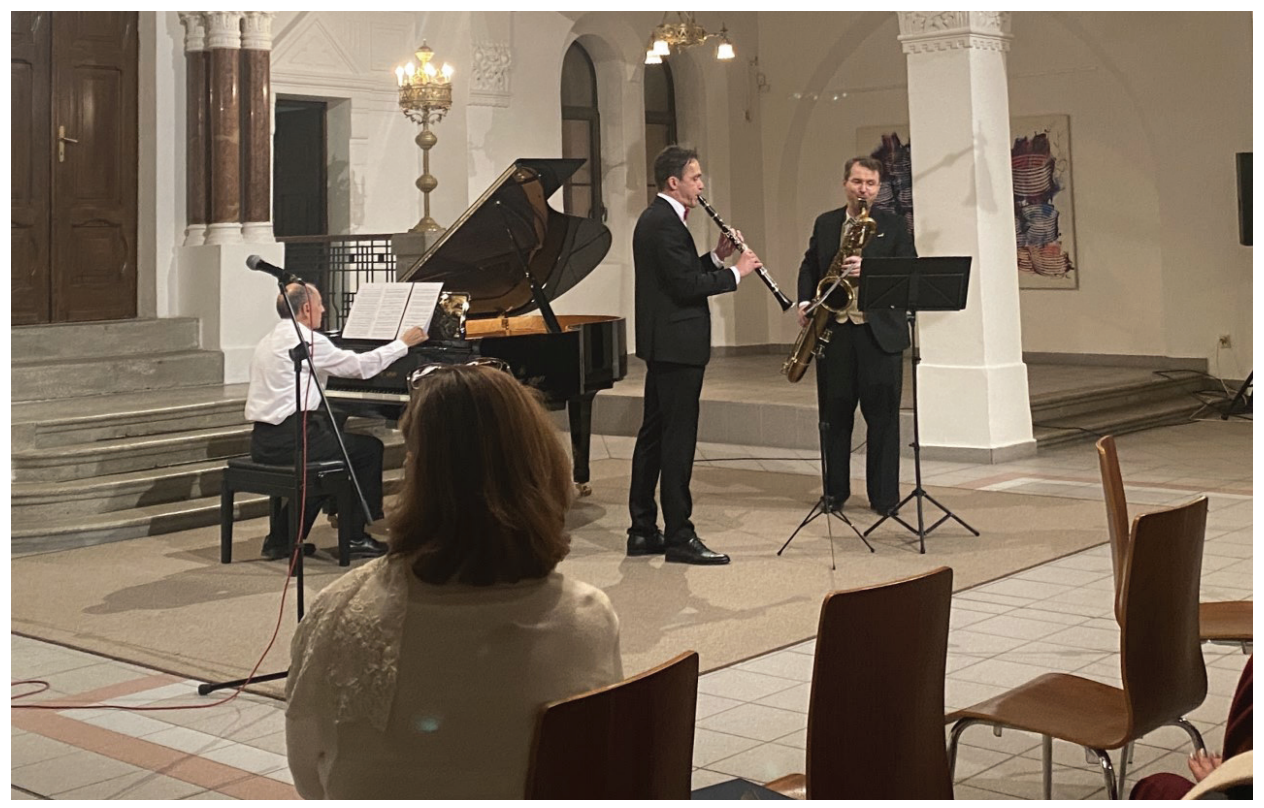

Obr. 3: Trio Elfair, 24. 11. 2021 
Klarinetista a pedagóg Jozef Eliáš je absolventom Konzervatória, VŠMU v Bratislave a doktorandského štúdia na Akadémii umení (prof. Alexander Stepanov) v Banskej Bystrici. Od roku 2008 pôsobí vo funkcii prvého klarinetistu Slovenskej filharmónie. Spolupracuje s mnohými významnými domácimi i zahraničnými orchestrami a komornými zoskupeniami (Slovenská filharmónia, Slovenské národné divadlo, Capella Istropolitana, Český národní symfonický orchester, Quasars Ensemble, Melos-Étos Ensemble, ŠKO Žilina, ŠF Košice, Moyzesovo kvarteto a i.).

$\checkmark$ úvode večera zaznela $z$ tvorivej dielne Jevgenija Iršaia v podaní Jozefa Eliáša (klarinet) a Ladislava Fanzowitza (klavír) Sonata del Grato. Iršai venoval dielo jednej z najvýznamnejších osobností slovenskej hudby druhej polovice 20. storočia - skladatel'ovi I. Zeljenkovi, o ktorom povedal, že „... bol a je obdivovatel'om jeho rozsiahlej tvorby... a každé osobné stretnutie ho neskutočne inšpirovalo." Sonata del Grato je výrazom vd'aky za vel'korysú morálnu podporu, ktorú skladatel' pocitoval zo strany kolegu v čase procesu svojej adaptácie sa na slovenské prostredie. Na ploche invenčne bohatej hudby so široko rozvibrovanou expresiou sa v interpretačne precíznom podaní Eliáša a Fanzowitza predierali na povrch spomienky na zeljenkovské motivické idiómy.

Po zvukovo zaujímavej Sonate del Grato nasledoval Monologue pre sólový barytónový saxofón, ktorý skladatel' venoval Ladislavovi Fanzowitzovi. Skvelý klavirista sa tak návštevníkom festivalu predstavil v úlohe technicky zdatného koncertného saxofonistu so zmyslom pre farebnost' a špecifickost' nástroja. Po Monologue nasledovala skladba pre klarinet a barytónový saxofón Silhouettes, ktorá vznikla na Fanzowitzovu objednávku. Dielo, pôvodne určené dvom saxofónom, zaznelo v autorskej úprave pre klarinet a barytónový saxofón v podaní zohratého dua Jozef Eliáš (klarinet) a Ladislav Fanzowitz (saxofón) citlivo vystihujúceho každý detail skladby.

Druhá polovica koncertu bola venovaná Jevgenijovi Iršaiovi už nielen ako skladatelovi, ale aj ako klaviristovi, ktorý sám i v komornej zostave uviedol nasledujúce tri skladby vo svetovej premiére. Prvou z nich bola v autorskej interpretácii Moonlight sonáta č. 2 pre klavír. Blízkost' názvu so svetoznámou Beethovenovou klavírnou Sonátou mesačného svitu nie je náhodná. Ako sa autor vyjadril, materiál, ktorý použil v prvej časti svojej zatial' poslednej klavírnej sonáty, v ňom ,.... evokoval pocit blízkosti s materiálom Beethovenovej sonáty", a preto „... po dlhšom uvažovaní sa ,drzo' odvážil pomenovat'svoju sonátu podobným názvom".

Vzápätí Iršai v spolupráci s L. Fanzowitzom uviedol cyklus troch skladieb s pomerne nezvyčajným názvom Šumafuk pre klavír štvorručne. Išlo o dielo, ktoré bolo skomponované priamo pre koncert 18. ročníka festivalu umení Konfrontácie 2021.V dramaturgii koncertu skladatel'ovi chýbala interaktivita s klaviristom Ladislavom Fanzowitzom, a preto na túto príležitost' skomponoval dielo, ktoré by si na koncerte mohli spoločne zahrat. Tak vznikol cyklus troch skladieb, z ktorých tretia je valčíkom inšpirovaným tvorbou D. Šostakoviča.

V závere večera sa Trio Elfair predstavilo v kompletnej zostave a vo svetovej premiére uviedlo skladbu Saxlibris. Dielo, pôvodne určené dvom saxofónom a klavíru, zaznelo na festivale v originálnej autorskej úprave pre klarinet, barytónový saxofón a klavír. Vysoký stupeň profesionality opierajúcej sa o dokonalú súhru interpretov bol presvedčivým záverom tretieho koncertu festivalu umení Konfrontácie 2021. 


\section{Štvrtok 25. november / $18.00 \mathrm{~h}$}

Štvrtkový večer priniesol organizátorom festivalu nejednu t’ažkú chvíl'ku, ked'sa z dôvodu uzavretia koncertného priestoru nitrianskej Synagógy v dôsledku protiepidemických opatrení (vyhlásených v stredu s platnostou od polnoci) musel koncert náhle preniest' do nových priestorov - do Pavilónu hudby v Nitre. Už bez prítomnosti publika, avšak vd’aka Západoslovenskej televízii v priamom prenose v online prostredí, sa konal koncert komorného súboru Quasars Ensemble pod vedením dirigenta Ivana Buffu a v spolupráci s renomovaným slovenskými interpretmi - organistom Marekom Štrbákom a speváčkou Evou Šuškovou.

Sopranistka Eva Šušková patrí medzi popredné slovenské interpretky komornej hudby. Okrem iného vyniká aj v interpretácii diel slovenských autorov 20. storočia spolupodielala sa na šiestich premiérach pôvodných slovenských opier skladatelov J. Beneša, V. Kubičku a S. Solovica. Spolupracovala tiež s poprednými orchestrami a súbormi (Prague Modern, Quasars Ensemble, Solamente naturali, Janáčkova filharmonie Ostrava, Slovenská filharmónia, Symfonický orchester Slovenského rozhlasu, Slovenský komorný orchester a d'.). Na svojom konte má početné vystúpenia na Slovensku i v zahraničí (Česko, Francúzsko, Rakúsko, Pol’sko). Výrazným momentom jej speváckej kariéry bolo naštudovanie Schönbergovej monodrámy Pierrot Lunaire či Benjaminovej komornej opery Into the Little Hill. Predstavila sa tiež v Opere SND v rôznych scénických postavách, napríklad ako Mercedes (Carmen), Kate Pinkerton (Madama Butterfly), Desdemona (Otello), Rusalka (Rusalka), Suzel (Priatel'Fritz) a iné.

Marek Štrbák, sólový a komorný hráč s bohatou koncertnou činnostou doma i v zahraničí, pravidelne spolupracuje so Slovenskou filharmóniou, Slovenským filharmonickým zborom a Štátnym komorným orchestrom Žilina. Je výnimočný aj tým, že

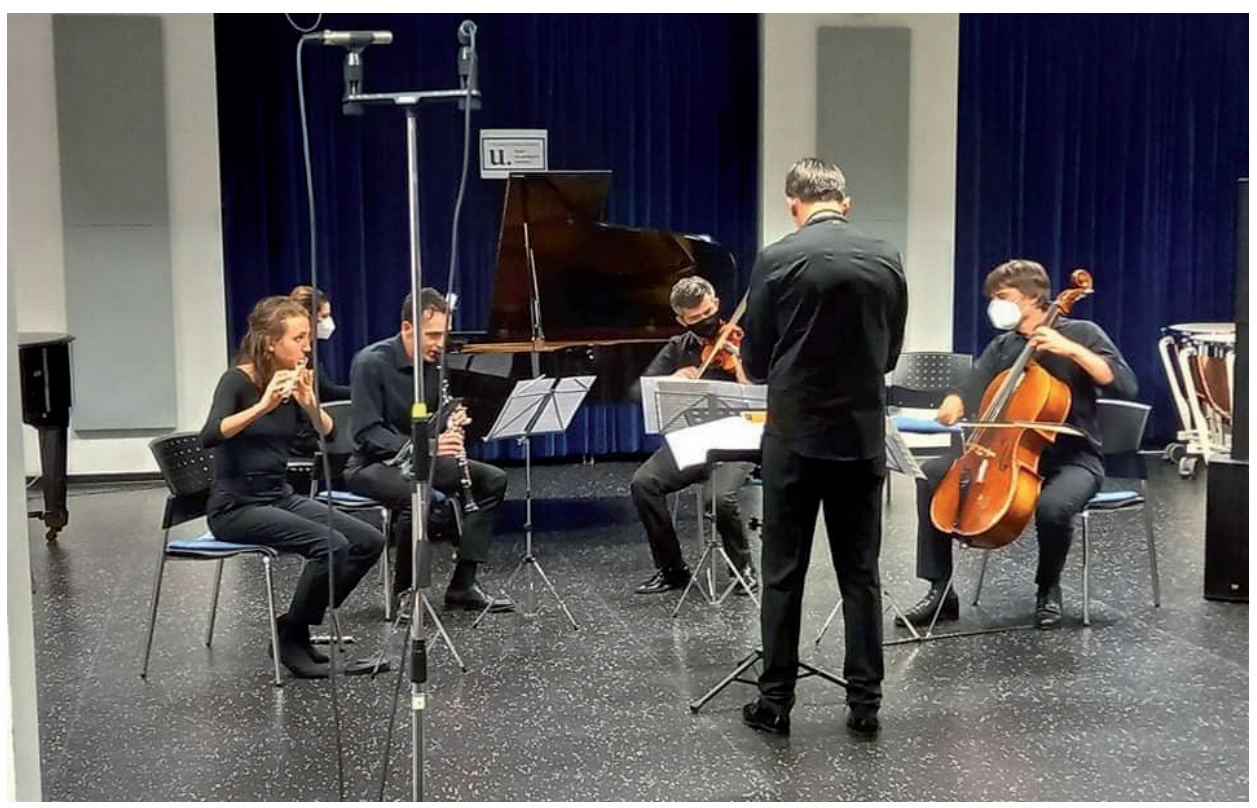

Obr. 4: Quasars Ensemble, 25. 11. 2021 
často interpretuje diela slovenských skladatel'ov, pričom mnohé z nich aj premiéroval. Pravidelne sa zúčastňuje na majstrovských interpretačných kurzoch pod vedením renomovaných európskych pedagógov a bol ocenený na niekol'kých domácich i medzinárodných sútažiach. V roku 2019 vyšlo jeho profilové CD s názvom Organová tvorba východoslovenských skladatelov.

Quasars Ensemble patrí k jedinečným profesionálnym medzinárodným hudobným telesám svojho druhu na Slovensku. Súbor vznikol v roku 2008 a popri súčasnej klasickej hudbe sa v rovnakej miere venuje aj hudbe starších epoch. Konfrontuje najnovšie súčasné diela s piliermi klasickej hudobnej histórie. Quasars Ensemble sa predstavil na najprestížnejšom pódiu súčasnej hudby - legendárnych 46. prázdninových letných kurzoch v Darmstadte. Účinkoval aj na Varšavskej jeseni, Arcus Temporum v Pannonhalme, Ostravských dňoch novej hudby. Je pravidelným hostom prestížnejších slovenských festivalov, akými nesporne sú Bratislavské hudobné slávnosti a Melos-Étos.

Úvod koncertu patril organovej tvorbe Štefana Németha-Šamorínskeho (1896 - 1975), konkrétne kompozícii Concerto per organo solo op. 85 (Con moto Naenia, Adagio dolente, Allegro non troppo). Napriek tomu, že toto organové dielo sa nehráva často, patrí medzi najkvalitnejšie organové skladby, ktoré vznikli na území Slovenska. V tomto roku si pripomíname 125 . výročie narodenia Šamorínskeho, a preto zaradenie tejto skladby do programu festivalu možno považovat' za významný dramaturgický počin. Reprodukcia skladby v podaní organistu Mareka Štrbáka vyznela presvedčivo, farebne rozmanito s potrebnými tempovými kontrastmi. Citel'ná bola tiež jeho dispozícia vytvárat' pôsobivé dynamické protipóly (od pianissima až po forte-fortissimo), plynulé dynamické gradácie i stíšenia. Obdivuhodná bola tiež jeho schopnost' citlivej, zvukovo rozmanitej a bohatej registrácie. Technicky erudovaný interpret dokázal, že aj súčasnú hudbu možno interpretovat’ podmanivo a pútavo a nepochybne si svojou interpretáciou získal nejedného poslucháča. V podaní M. Štrbáka si poslucháči tiež mohli vypočut' skladby Corale a Chaconne pre organové sólo od skladatela a dirigenta Ivana Buffu, pričom Chaconne mala na tomto festivale premiéru.

Okrem organistu Mareka Štrbáka sa na štvrtkovom koncerte predstavil tiež komorný súbor Quasars Ensemble. V ich stvárnení zaznela skladba Fresco pre komorný súbor piatich nástrojov Ivana Buffu. Dielo vzniklo pôvodne na objednávku festivalu Muzički Biennale Zagreb začiatkom tohto roka (2021) a súčasne je spomienkou na Jozefa Podprockého, ktorý ako pedagóg skladatel’a I. Buffu inšpiroval k používaniu dvanást'tónového radu. Charakteristickými pre túto skladbu sú netypické polohy a techniky hry na jednotlivých hudobných nástrojoch, komplikovaný rytmus a disonancia.

Záver koncertu patril vokálno-inštrumentálnemu dielu Korczak in memoriam pre mezzosoprán, flautu, organ, sláčikové kvarteto a tympany od významného avantgardného skladatela Romana Bergera (1930 - 2020). Toto náročné dielo si vyžadovalo obrovskú koncentráciu všetkých umelcov smerujúcu k zvukovej vyváženosti a vzájomnému porozumeniu v súhre, ústiacu do filozoficky híbavého a ludsky dojímavého príbehu obety. Obety zosobnenej židovským pedagógom Januszom Korczakom, ktorý neuteká, hoci môže, a spoločne so svojimi chránencami sa dobrovolne uberá do plynovej komory varšavského geta... V kontexte hudobného toku bol nesmierne pútavým vstup speváčky Evy Šuškovej, ktorá špecificky ladený part zaspievala opravdivo a precítene a skladbe dodala potrebný dramatický podtón. 


\section{Piatok 26. november / $18.00 \mathrm{~h}$}

Na záverečnom koncerte 18. ročníka festivalu umení Konfrontácie sa v programe Hudba a poézia predstavila trojica interpretov: operná speváčka Eva Šušková, klavirista Ivan Koska a herec Štefan Bučko.

Ivan Koska študoval hru na klavíri v Bratislave na Štátnom aj Cirkevnom konzervatóriu, bakalársky titul získal na Konzervatóriu F. Torrefranca v Taliansku. V štúdiu pokračoval na Arts Academy v Ríme a na Medzinárodnej klavírnej akadémii Incontri col maestro v Imole. Doktorandské štúdium v klavírnej interpretácii úspešne ukončil na Louisiana State University v Baton Rouge v roku 2015. Je vítazom viacerých klavírnych sútaží, koncertoval ako sólový a komorný hráč v Taliansku, Spojených štátoch amerických, Nemecku, Vel'kej Británii, Brazílii a aj na Slovensku. Venuje sa komornej hudbe a je pravidelným partnerom popredných slovenských a zahraničných interpretov. Popri klavírnej interpretácii sa zaoberá aj prekladatel'stvom, a to predovšetkým hudobných textov z viacerých jazykov, a je tiež organizátorom úspešného koncertného cyklu Hudba v Pezinku.

Štefan Bučko absolvoval Divadelnú fakultu VŠMU a hned' po skončení dostal angažmán v Činohre SND, kde pôsobí dodnes. V rokoch 2008 - 2010 stál na čele súboru, kde sa sústredil na systematický rozvoj pôvodnej tvorby a premiéry svetových titulov, ktoré sa na Slovensku neuvádzali. Zúčastnil sa viacerých sútaží v umeleckom prednese a na recitáloch sa predstavil doma i v zahraničí. V roku 2013 vystúpil spolu so Slovenským filharmonickým zborom a Symfonickým orchestrom SF v Paríži v premiére oratória Egona Kráka Cirillo-Metodiada. Ďalším úspechom bola premiéra melodrámy Mareka Piačka Apolloopera pre recitátora, zbor a trombón v bratislavskej Redute a na festivale Opera Nova 2018 v Prahe. V roku 2016 dokončil pre Slovenský rozhlas nahrávanie jedného z klúčových diel svetovej literatúry - Danteho Božskú komédiu.

Piatkový večer sa niesol v netradičnom spojení hudby s umením poézie. V úvode Eva Šušková v sprievode Ivana Kosku predstavila piesňový cyklus Tri básne Stéphana Mallarmého (Vzdych, Drobná žiadost'a Vyšlahnúc z pätky, z výplne...) francúzskeho hudobného skladatela Maurica Ravela (1875 - 1937), ktorý bol doplnený poetickým prednesom zhudobnených básní Stéphana Mallarmého (1845 - 1898) v podaní Štefana Bučka.

Nasledovala prezentácia vybraných piesní z cyklu Nox et solitudo pre mezzosoprán a klavír od Eugena Suchoňa (1908 - 1993) - Zmráka sa a Topole. Cyklus piatich piesní vychádza z pôvodnej básnickej zbierky Nox et solitudo od Ivana Kraska (1876 - 1958) a je založený na princípe kontrastu jednotlivých zložiek, ktoré spojením spevu s klavírom prehlbujú význam a krásu vybraných básní. Piesne opätovne svojím citlivým prednesom pretkal Š. Bučko, ktorý poslucháčom z danej básnickej zbierky predniesol básne Plachý akord a Romaneto (1909).

Piesňový cyklus Láska a život ženy op. 42 (piesne Odkedy som ho zazrela a Nerozumiem tomu) romantického skladatel'a Roberta Schumanna (1810 - 1856) vznikol zhudobnením básní Adelberta von Chamissa (1781 - 1838). Tvorí ho osem piesní prinášajúcich citové rozpoloženie dievčat’a, ktoré sa stáva ženou. Jednotlivé piesne sú vnútorne prepojené, objavujú sa v nich leitmotívy i určitá symbolika. Opakovanie vybraných tónin, podobných motívov a rytmických štruktúr v klavírnom sprievode naznačujú momentálny stav dospievajúcej ženy a náladu danej piesne. Hudbu plynulo striedal umelecký prednes básní Sladký priatelu, Na mojom srdci a Práve si mi z básnickej zbierky Tri sonety (1922) od Rainera Mariu Rilkeho (1875 - 1926). 
V druhej polovici koncertného večera mali poslucháči možnost' vypočut' si v podaní Š. Bučka jednu z najznámejších romantických balád slovenskej literárnej tvorby Zakliata panna vo Váhu a divný Janko Janka Krála (1822 - 1876). Dielo predstavuje adaptáciu rozprávky o zakliatej panne, ktorá svojou čarovnou mocou omámi Janka a ktorý v snahe oslobodit ju zomiera vo vinách Váhu. V súlade s básnickou tvorbou inšpirovanou slovenskou l'udovou slovesnostou predstavila Eva Šušková s Ivanom Koskom následne pieseň Kopala studienku z piesňového cyklu Pät' ludových piesní pre hlas a klavír (1975) Jána Cikkera (1911 - 1989), ktorý je jedným z mimoriadne silných prejavov vztahu skladatela k slovenskému folklóru.

V závere posledného koncertu 18. ročníka festivalu umení Konfrontácie odznel v podaní Š. Bučka

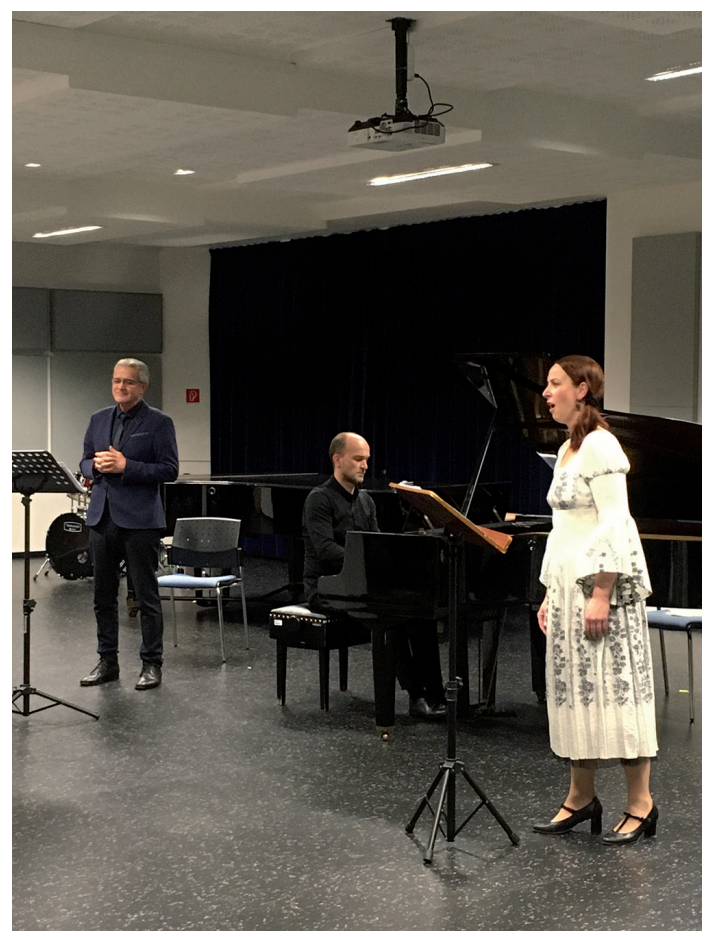

Obr. 5: Eva Šušková, Ivan Koska, Štefan Bučko, 26. 11.2021 klenot slovenskej literatúry - básnická skladba Marína od Andreja Sládkoviča (1820 - 1872), v ktorej sa prelína láska k vlasti s láskou k žene. Dielo obsahuje prvky lúbostnej a reflexívnej lyriky, ako aj baladické prvky prameniace z autorovej neštastnej lásky. Koncert napokon uzavrel výber piesní z piesňového cyklu Dedinské scény pre spev a klavír (Svadba, Ukoliebavka a Tanec mládencov, 1924) Bélu Bartóka (1881 - 1945).

Citlivý spevácky výraz, precíznu intonáciu a dynamickú prácu s intenzitou hlasu v interpretácii piesní doplnil prirodzený dramatický prejav E. Šuškovej, ktorej vnímavým partnerom bol Ivan Koska - technicky zdatný klavirista s bohatou škálou výrazových polôh, nikdy neprekrývajúci, ale vždy umne dopĺñajúci hudobný kontext. Hodnotit' vklad Štefana Bučka do večera plného poézie a hudby nemožno inak ako len v superlatívoch. Podmanivý témbr hlasu, precízna artikulácia, zmysel pre pointu a v neposlednom rade nádherná slovenčina urobili zo záverečného koncertu festivalu nezabudnutel'ný zážitok.

Osemnásty ročník festivalu umení Konfrontácie, snažiaci sa v dramaturgickej koncepcii o dialóg medzi umením súčasným a minulým, naplnil očakávania umeniamilovnej verejnosti a nielen nitrianskemu publiku, ale aj divákom Západoslovenskej televízie, predstavil v pútavej, bohatej a pestrej dramaturgii vysoko kvalitné výkony slovenských i zahraničných umelcov. Sledovanost’ jednotlivých koncertov v online prostredí svedčí o tom, že aj napriek komplikovanej epidemickej situácii si festival umení Konfrontácie aj v tomto roku uchoval priazeň milovníkov umenia. 